\title{
Do Emigrant’s Remittances Cause “Dutch Disease”? : The Case of Nepal and Bangladesh
}

\author{
Hiroyuki Taguchi ${ }^{1, *} \&$ Bikram Lama $^{1}$ \\ ${ }^{1}$ Dept. of Japanese and Asian Studies, Saitama University, 255 Shimo-Okubo, Sakura-ku, \\ Saitama 338-8570, Japan \\ *Correspondence: Dept. of Japanese and Asian Studies, Saitama University, 255 \\ Shimo-Okubo, Sakura-ku, Saitama 338-8570, Japan. Tel: 81-48-858-3324, Fax: \\ 81-48-858-3696 E-mail: tagusaya0710@s3.wh.qit.ne.jp
}

Received: September 20, 2019 Accepted: October 10, 2016 Published: November 3, 2016 doi:10.5296/rae.v8i4.10044ＵRL: http://dx.doi.org/10.5296/rae.v8i4.10044

\begin{abstract}
This paper examines the Dutch Disease effects of international migrant remittances by using a vector auto-regression estimation focusing on Nepal and Bangladesh. The reason for targeting two economies is that the differences in their economic performances could shed light on what kinds of mechanisms make the received remittances lead to or not to the Dutch Disease. The study identified the existence of the Dutch Disease in Nepal, but not in Bangladesh, judging from the causalities and dynamic responses from remittances to manufacturing-services ratio. We speculate that the contrast in the Dutch Disease effects might come from the differences in the demand structure and policy efforts for manufacturing development between both economies.
\end{abstract}

Keywords: Remittances, Dutch Disease, Nepal, Bangladesh, Vector Auto-regression Estimation 


\section{Introduction}

International migrant remittances has increasingly become significant as one of the major sources of foreign exchange earnings for a large number of developing economies in terms of both growth rate and magnitude. The remittances received by developing economies showed the rapid increase from 44 billion US dollars in 2000 to 276 billion in 2014 by around six times, while the GDP of developing countries grew by four times during the same period. The remittance-GDP ratio averaged in developing economies reached about 2.0 percent in 2014, and it exceeded the foreign aid-GNI ratio (0.6 percent) averaged in developing countries in 2014.(Note 1)

These trends of the remittances have attracted great concerns for researchers and policy makers to analyze their economic implications. From the microeconomic perspectives, there have been intensive studies of their impacts on household incomes, poverty alleviation, school attendance, entrepreneurship and so forth. For the macroeconomic aspect, on the other hand, the central arguments have been whether remittances could cause "Dutch Disease": remittances would lead to a decline in the production of tradable sectors relative to non-tradable ones through a real exchange rate appreciation.

This paper examines the Dutch Disease effects of international migrant emittances by using an analytical framework of a vector auto-regression (VAR) estimation focusing on Nepal and Bangladesh as remittance recipients. The reasons why we target the both economics are as follows. First, Nepal and Bangladesh represent high presences as the recipients of remittances in the world. Table 1 reports that in the value of received remittances, Bangladesh accounts for 3.6 percent, which ranks sixth in developing countries. It also indicates that in the remittance-GDP ratio, Nepal records around 30 percent, which ranks first in developing economies. According to Figure 1, in both of Nepal and Bangladesh, the remittance-GDP ratio has been far exceeding the foreign aid-GDP ratio and inward foreign direct investment-GDP ratio, since the 2000s. Second, Nepal and Bangladesh represent a contrast in their economic performances, although they both depend highly on the received remittances in their economies and belong to the same area of South Asia. Figure 2 tells us that since the 2000s Bangladesh has achieved around 6 percent economic growth whereas Nepal has stayed at about 4 percent growth. This contrast in their performances could uncover the insight: what kinds of mechanism would make the received remittances lead to or not to the Dutch Disease, through the differences in their economic structures.

The rest of the paper is structured as follows. Section 2 describes the literature review on micro- and macro-economic impacts of remittances, in particular, on their Dutch Disease effects. Section 3 represents empirics on the Dutch Disease effects in Nepal and Bangladesh: data for key variables, methodologies for a VAR estimation, and the estimation outcome with its interpretation. The last section summarizes and concludes.

\section{Literature Review}

Regarding the literature of empirical studies on the economic impacts of remittances, the 
microeconomic aspects such as household incomes and poverty alleviation have been predominantly centred in their researches, with a relatively scanty treatment of macroeconomic aspects. From the microeconomic perspectives, the positive effects of remittances for the recipient developing economies were identified on poverty and income distribution (e.g., Adams and Page, 2005; Acosta, et al., 2008), on school attendance (e.g., Gorlich, et al., 2007), on entrepreneurship of microenterprises (e.g., Woodruff and Zenteno, 2001; Yang, 2005) and on financial development (e.g., Aggarwal, et al., 2006; Chowdhury, 2011).

Table 1: Major Recipients of International Migrant Remittances in 2014

\begin{tabular}{llll}
\hline Country & USD mil. & $\begin{array}{l}\text { \% of } \\
\text { Developing Countries }\end{array}$ & \% of GDP \\
\hline India & 70,389 & 17.1 & 3.4 \\
Philippines & 28,403 & 6.9 & 10.0 \\
Mexico & 24,462 & 5.9 & 1.9 \\
Nigeria & 20,829 & 5.1 & 3.7 \\
Pakistan & 17,066 & 4.1 & 6.8 \\
Bangladesh & 14,983 & 3.6 & 8.7 \\
Indonesia & 8,551 & 2.1 & 1.0 \\
Lebanon & 7,404 & 1.8 & 14.9 \\
Sri Lanka & 7,036 & 1.7 & 9.4 \\
Korea, Republic of & 6,481 & 1.6 & 0.5 \\
Guatemala & 5,837 & 1.4 & 9.9 \\
Nepal & 5,770 & 1.4 & 29.6 \\
Thailand & 5,655 & 1.4 & 1.4 \\
Dominican Republic & 4,810 & 1.2 & 16.8 \\
El Salvador & 4,235 & 1.0 & \\
\hline
\end{tabular}

Source: UNCTAD Stat, http://unctadstat.unctad.org/EN/.

For the macroeconomic viewpoint, the central arguments have been focused on whether remittances could cause the Dutch Disease. The theoretical framework of analyzing the Dutch Disease effect of "capital inflows" in small open economies was based largely on the Salter-Swan-Corden-Dornbusch model. Corden and Neary (1982) originally described this model as follows: capital inflows, through raising higher disposal income and aggregate demand, trigger higher relative prices of non-tradable goods (spending effect) that corresponds to a real exchange rate appreciation; this causes further movement of resources toward nontrade sector away from tradable sector (resource movement effect). This Dutch Disease model has been applied to examine the economic impacts of international migrant remittances, since they constitutes one of the major elements as an origin of capital inflows.(Note 2) There have been, however, relatively few studies that intend to apply the model in the context of investigating the economic impacts of remittances. 


\section{Macrothink}
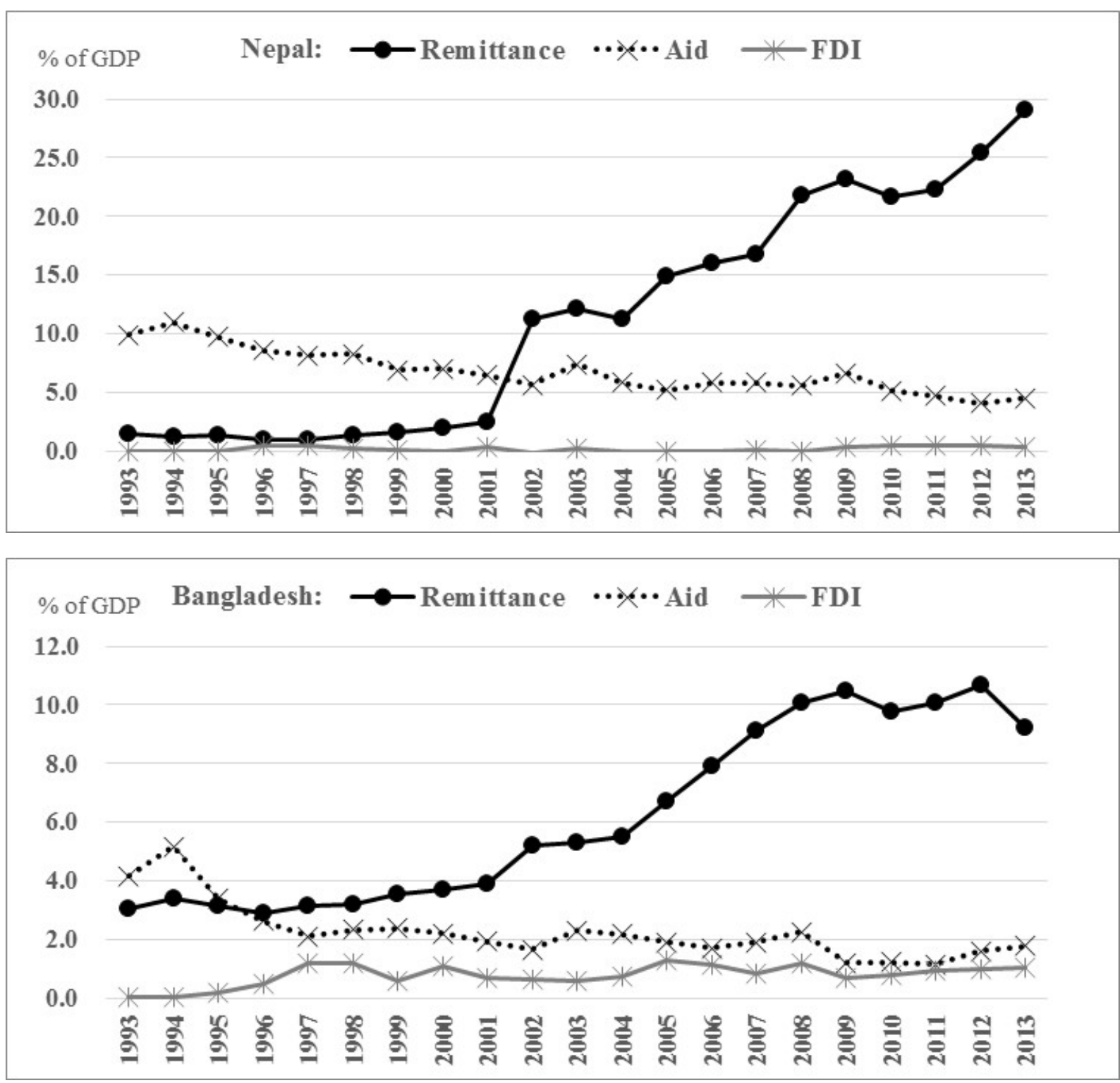

Sources: Remittance, GDP and Aid (net ODA): World Development Indicators (World Bank); FDI: UNCTAD Stat

Figure 1: Comparison among Remittance, Aid and FDI in Nepal and Bangladesh

Acosta, et al. (2009) applied the Dutch Disease model to analyzing the effects of remittances by estimating a dynamic stochastic general equilibrium model using the data of El Salvador and the Bayesian technique. They extended the original model by incorporating an additional transmission mechanism of remittances through labour supply: remittances increase the reservation wage of recipients and, thus, cause a decline in labour supply; a shrinking labour supply accompanies a higher wage that, in turn, leads to higher production costs and a further contraction of the tradable sector. Through the estimation, they identified the existence of the Dutch Disease effects of remittances: the reallocation of labour away from tradable sectors toward non-tradable sectors. From the viewpoint of different time-horizon, however, Bourdet and Falck (2007) argued that in the longer-term, an increase in emigrants' remittances would 
rather boost capital accumulation through their effects on domestic saving and investment, thereby resulting in the expansion of the production of both tradables and non-tradables. By examining the case of Cape Verde, they found the Dutch Disease effects from remittances was not so large, and suggested that growth- and export-oriented policies could contribute to limiting the Dutch Disease effect.

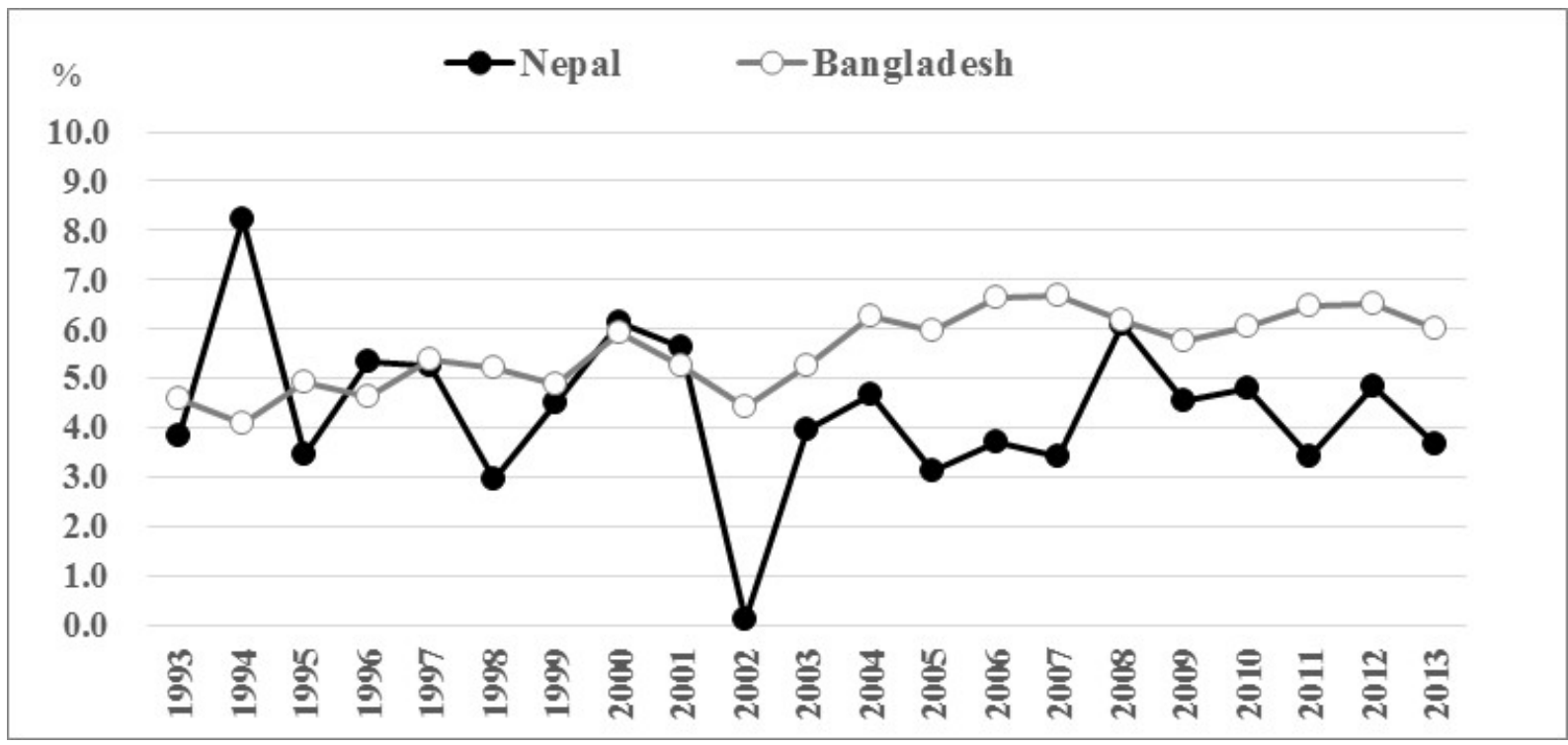

Sources: UNCTAD Stat

Figure 2: GDP Growth Rate in Nepal and Bangladesh

The comprehensive empirics of applying the Dutch Disease model to the remittance assessment was conducted by Lartey, et al. (2012), using an unbalanced panel data set containing 109 developing and transition countries for the period 1990-2003. They found that rising levels of remittances had "spending effects" that led to real exchange rate appreciation, and also "resource movement effects" that favored the nontradable sector sacrificing tradable goods production. By using the samples of 27 countries in the 1980 s and 28 countries in the 1990s, on the other hand, Fayad (2011) identified a transmission channel through which remittances were conductive to the relative growth of exporting industries within the manufacturing sector of recipient economies, contrary to what the standard Dutch Disease theory suggested.

In this way, even among the limited studies on the application of Dutch Disease model to emittance assessment, the theoretical outcomes have remained unsettled in the time horizons between short and long term, and the empirical evidence has also been inconclusive.

In this context, this study contributes to shedding light on what kinds of mechanisms would make the received remittances lead to or not to the Dutch Disease, since the study deals with contrasting cases of Nepal and Bangladesh: they differ in their economic performances under their common dependence on remittances. The technical contribution is the adoption of a VAR estimation for the Dutch Disease analysis, which enables us to avoid the endogeneity 
problem of remittance variable.

\section{Empirics}

This section represents empirics for remittance assessment under the Dutch Disease framework for Nepal and Bangladesh: data for key variables, methodologies for a VAR model estimation, and the estimation outcomes with its interpretation.

\subsection{Data for Key Variables}

At the beginning, we identify economic variables for a VAR model estimation in Nepal and Bangladesh. Since the purpose of analysis is to examine the economic impact of remittances under the Dutch Disease framework, we pick up three endogenous variables: remittances as a percentage of GDP (roy), real exchange rate (rer), and the ratio of manufacturing relative to services in GDP base (mos). The real exchange rate is included for investigating "spending effects", while the manufacturing-services ratio is for examining "resource movement effects". As was in Lartey, et al. (2012), the manufacturing sector is assumed to be a proxy of tradables, while the service sector is that of non-tradables. The Dutch Disease would be implied, if the ratio declined with an increase in received remittances. The reason why we focus only on these limited number of variables is to maximize the degree of freedom in the estimation within the short-range of annual data from 1993 to 2013.

Regarding the variable for remittance-GDP ratio, the data for remittances and GDP are retrieved from World Development Indicators (WDI) of the World Bank.(Note 3) The real exchange rate is computed in the following way (taking Nepalese one as an example).

$$
\operatorname{rer}_{\text {Nepal }}=\left\{C P I_{\text {Nepal }} / \text { er }_{\text {Rupees per US Dollar }}\right\} / \text { WIUV }
$$

where $C P I$ is consumer price index $(2010=100)$ in Nepal; er is nominal exchange rate in terms of Rupees per US Dollar; and WIUV is the world import unit value. The consumer price index, nominal exchange rate and the world import unit value are taken from International Financial Statistics of International Monetary Fund. The manufacturing-services ratio is derived by dividing "manufacturing in value-added term" by "services in value-added one”, both of which are retrieved from UNCTAD STAT.(Note 4)

Figure 3 displays the overviews of three key variables: remittance-GDP ratio, real exchange rate and manufacturing-services ratio in Nepal and Bangladesh for the period from 1993 to 2013. We could roughly observe a clear contrast in the trends in variables between Nepal and Bangladesh as follows. Regarding the remittance-GDP ratio, those of Nepal and Bangladesh showed similar increasing trends even under their different levels. As for the real exchange rate, however, Nepal represented an increasing trend, while Bangladesh had no clear trend. The manufacturing-services ratios revealed a clear contrast: Nepal showed a declining trend whereas Bangladesh had an increasing one. This observation implied the existence of the Dutch Disease in Nepal and its non-existence in Bangladesh. The observation should, however, be statistically tested by a more sophisticated manner, i.e., a VAR model estimation 
as in the following sub-section 3.2. For the VAR estimation, we will convert all the data into natural logarithm form.

[Nepal]
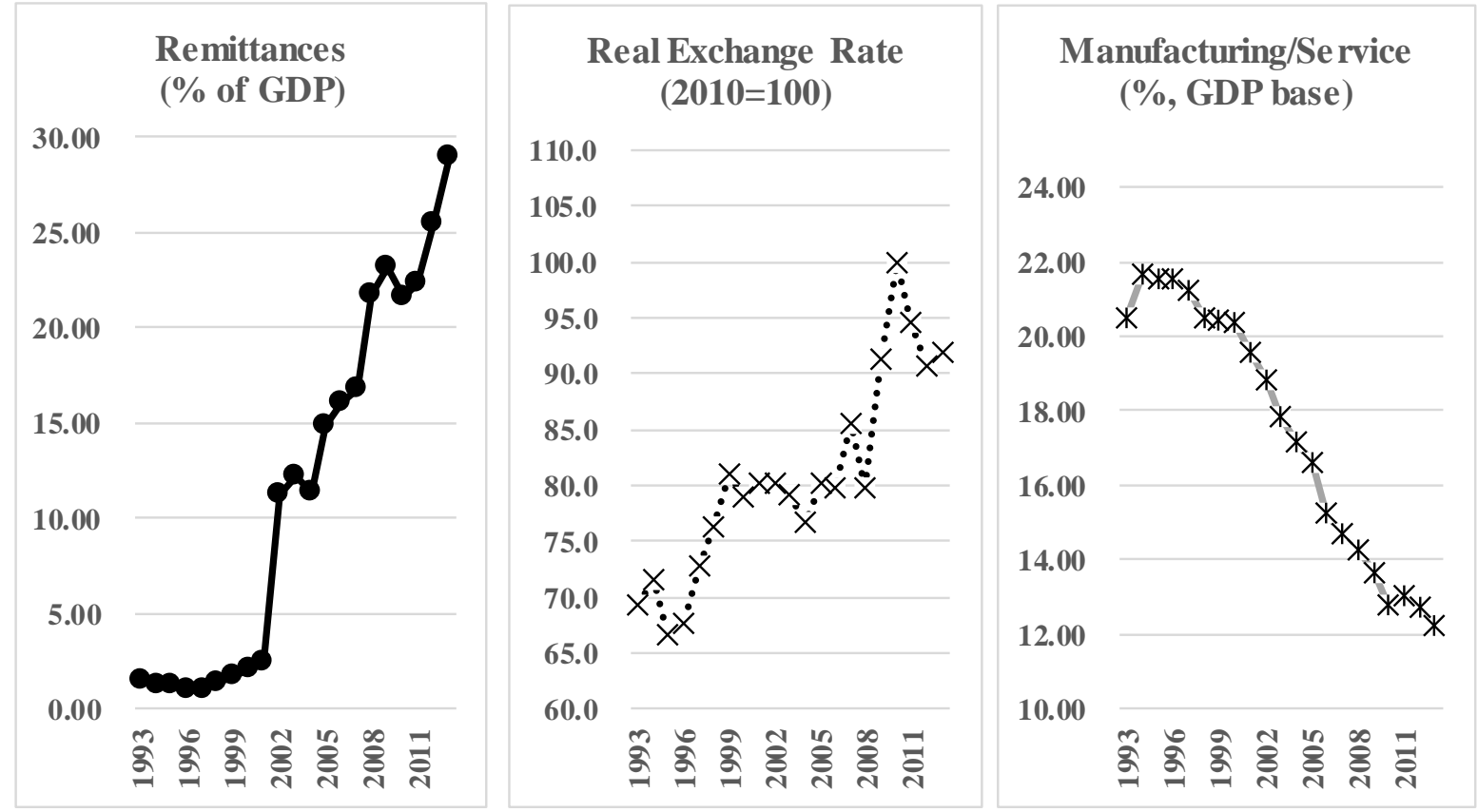

\section{[Bangladesh]}
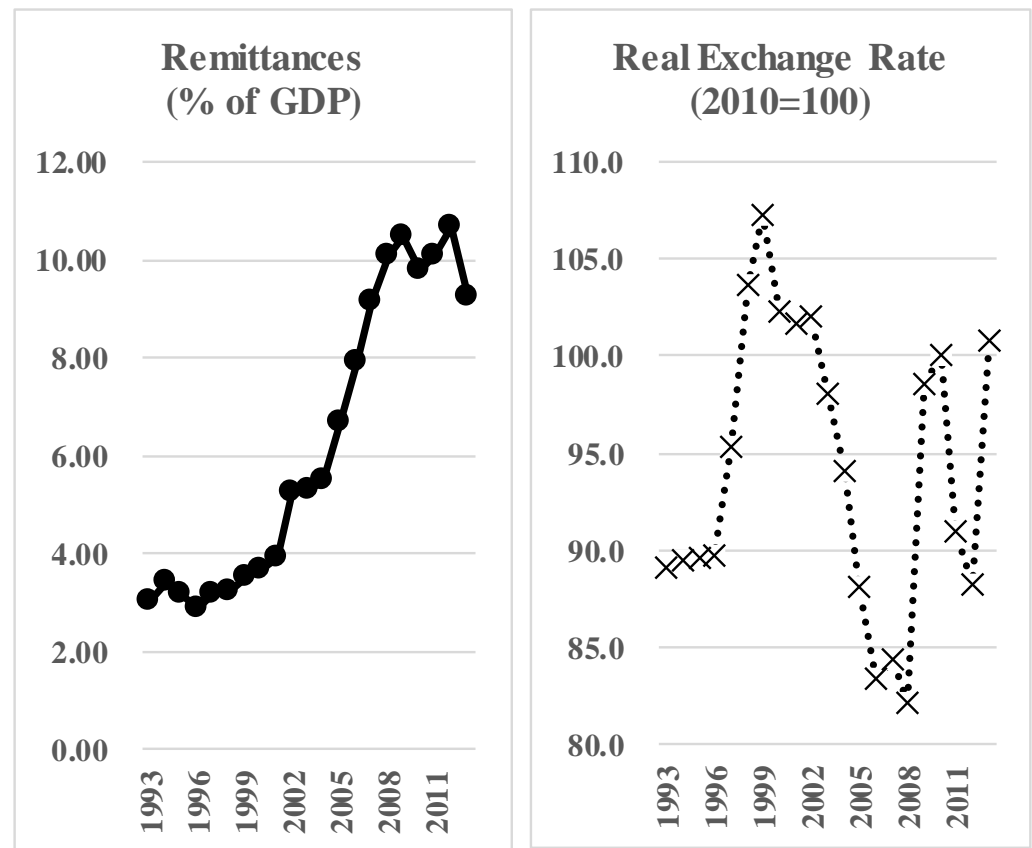

\section{Manufacturing/Se rvice (\%, GDP base)}

32.00

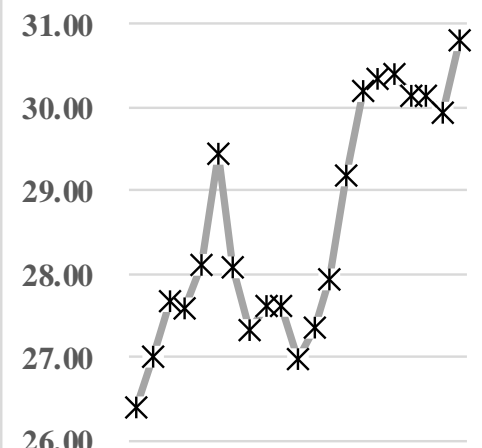

25.00 ๙

Source: World Development Indicators (World Bank), International Financial Statistics (International Monetary Fund) and UNCTAD Stat.

Figure 3: Overviews on Nepal and Bangladesh 


\subsection{Methodologies for a VAR Model Estimation}

We herein conduct a VAR model estimation. The reason why we adopt a VAR model for our remittance assessment is that the VAR model allows for potential and highly-likely endogeneity between the variables of interest, and also for tracing out the dynamic responses of variables to exogenous shocks overtime.

Before specifying a VAR model, we investigate the stationary property of the data, by employing a unit root test for each variable's data, and if needed, a cointegration test for a set of variables' data. The unit root test is conducted on the null hypothesis that a level and/or a first difference of the individual data have a unit root. In case that the unit root test tells us that each variable' data are not stationary in the level with a unit root, but stationary in the first-difference, a set of variables' data correspond to the case of $I(1)$, and then can be further examined by a cointegration test for the "level” data. If a set of variables' data are identified to have a cointegration, the use of the "level" data is justified for a VAR model estimation. For a unit root test, we adopt the augmented Dickey-Fuller (ADF) test (see Said \& Dickey, 1984), and for a cointegration test, we employ the Johansen test (see Johansen, 1995). The both tests are conducted by including "intercept" in the test equation. Table 2 reports the result of both unit root and cointegration tests. For the data of all three variables in both countries, i.e., remittances-GDP ratio (roy), real exchange rate (rer), and manufacturingservices ratio $(m o s)$, the unit root test identified a unit root in their levels, but rejected it in their first differences at the conventional level of significance, thereby the variables following the case of $I(1)$. The cointegration test was, thus, conducted further, and both the trace test and the Maximum-eigenvalue test indicated that the level series of all three variables' data were cointegrated in both countries. We thus finally utilize the level data for a VAR model estimation.

Table 2: ADF Unit Root Test and Johansen Cointegration Test

\begin{tabular}{lllll}
\hline & \multicolumn{2}{c}{ Unit Root Test } & \multicolumn{2}{c}{ Cointegration Test } \\
\cline { 2 - 5 } & Level & First Difference & Trace & Max-eigen \\
\hline Nepal & & & & \\
roy & -0.46 & $-4.07^{* * *}$ & & \\
rer & -1.09 & $-4.90^{* * *}$ & $42.99 * * *$ & $27.22^{* * *}$ \\
mos & 1.31 & $-4.22^{* * *}$ & & \\
\hline Bangladesh & & & & \\
roy & -1.31 & $-3.27^{*}$ & & $26.08^{* *}$ \\
rer & -2.44 & $-3.55^{*}$ & $42.47^{*}$ & \\
mos & -2.60 & $-3.39^{*}$ & & \\
\hline
\end{tabular}

Note: $* * *, * * *$ denote rejection of null hypothesis at the $99 \%, 95 \%$ and $90 \%$ level of significance, respectively.

We now specify a VAR model equation for estimation in the following way.

$$
y_{t}=\mu+V y_{t-1}+\varepsilon_{t}
$$


where $y_{t}$ is a $(3 \times 1)$ column vector of the endogenous variables: $y_{t}=\left(\text { roy }_{t} \text { rer }_{t} \text { mos }_{t}\right)^{\prime}, \mu$ is a (3 $\times 1)$ constant vector, $V$ is a $(3 \times 3)$ coefficient matrix, $y_{t-1}$ is a $(3 \times 1)$ vector of the lagged endogenous variables, and $\varepsilon_{t}$ is a $(3 \times 1)$ vector of the random error terms in the system. The lag length (-1) is selected by the minimum Akaike Information Criterion (AIC) with maximum lag equal to $(-2)$ under the limited number of observations.

Based on the VAR model estimation, we examine the bilateral Granger causalities among three endogenous variables, and also investigate the impulse responses to the shock of remittance-GDP ratio so that we can trace the 8-year dynamic effects. As for the methodology to define the impulse responses, we adopt the "generalized impulse response" proposed by Pesaran and Shin (1998). This approach, unlike the traditional impulse response analysis, does not require orthogonalization of shocks and is invariant to the ordering of the variables in the VAR model.

\subsection{Estimation Outcomes and Its Interpretation}

Table 3, Table 4 and Figure 4 respectively report estimation outcomes of the VAR model, the bilateral Granger causalities and the impulse responses.

Table 3: Estimated VAR Model

\begin{tabular}{llll}
\hline Nepal & roy & rer & mos \\
\hline roy -1 & $0.982^{* * *}$ & -0.012 & $-0.033^{* * *}$ \\
& {$[5.968]$} & {$[-0.512]$} & {$[-2.926]$} \\
rer -1 & 2.571 & $0.463^{* *}$ & -0.041 \\
& {$[1.722]$} & {$[2.133]$} & {$[-0.398]$} \\
mos -1 & 1.290 & -0.328 & $0.816^{* * *}$ \\
& {$[0.951]$} & {$[-1.662]$} & {$[8.537]$} \\
C & -14.765 & $3.322^{* *}$ & 0.740 \\
& {$[-1.554]$} & {$[2.404]$} & {$[1.106]$} \\
adj $R^{\wedge} 2$ & 0.926 & 0.770 & 0.985 \\
\hline Bangladesh & $r o y$ & $r e r$ & $m o s$ \\
roy -1 & $1.017 * * *$ & $-0.088^{*}$ & 0.017 \\
& {$[12.264]$} & {$[-1.948]$} & {$[1.272]$} \\
rer -1 & 0.088 & $0.519^{* * *}$ & $-0.154^{* * *}$ \\
& {$[0.283]$} & {$[3.048]$} & {$[-2.920]$} \\
mos ${ }_{-1}$ & -0.528 & $0.859^{*}$ & $0.697 * * *$ \\
C & {$[-0.666]$} & {$[1.987]$} & {$[5.187]$} \\
& 1.390 & -0.541 & $1.692^{* * *}$ \\
adj $R^{\wedge} 2$ & {$[0.537]$} & {$[-0.383]$} & {$[3.855]$} \\
& 0.954 & 0.454 & 0.865 \\
\hline
\end{tabular}

Note: ***, **, * denote rejection of null hypothesis at the $99 \%$, 95\% and $90 \%$ level of significance, respectively. 
Regarding the bilateral Granger causalities shown in Table 4, it was only the causality from remittances-GDP ratio (roy) to manufacturing- services ratio (mos) that was identified at the highly significant level in Nepal. Considering the estimated VAR model in Table 3, this causality was supposed to be the "negative” one. In Bangladesh, on the other hand, the weak "positive” causality from remittances-GDP ratio (roy) to manufacturing- services ratio (mos) was observed. As for the impulse responses shown in Figure 4, the manufacturing-services ratio negatively responded to the shock of remittances-GDP ratio within a 95 percent error band in Nepal, while the manufacturing-services ratio positively responded to that shock in Bangladesh, as the 8-year dynamic effects.

The implications of the estimation outcomes above are summarized as follows. First, Nepal would suffer from the Dutch Disease. It should be, however, noted that an increase in remittances did not accompany real exchange rate appreciation, judging from no causality and no significant impulse response from the remittances-GDP ratio to the real exchange rate. The Dutch Disease in Nepal could be interpreted such that remittances shrank tradable sector directly through a decline in labour supply as Acosta, et al. (2009) suggested as an additional transmission mechanism. Second, Bangladesh would have no Dutch Disease effects, and even enjoy the expansion of tradable sector. This effect might be coming from capital accumulation as Bourdet and Falck (2007) suggested as a long-term impact of remittances.

Table 4: Bilateral Granger Causality Tests

\begin{tabular}{|c|c|c|c|}
\hline Nepal & Lags & Null Hypothesis & F-Statistic \\
\hline \multirow[t]{2}{*}{ roy \& rer } & 1 & roy does not Granger Cause rer & 1.62 \\
\hline & & rer does not Granger Cause roy & 2.08 \\
\hline \multirow[t]{2}{*}{ roy \& mos } & 1 & roy does not Granger Cause mos & $8.85 * * *$ \\
\hline & & mos does not Granger Cause roy & 0.00 \\
\hline Bangladesh & Lags & Null Hypothesis & F-Statistic \\
\hline \multirow[t]{2}{*}{ roy\& rer } & 1 & roy does not Granger Cause rer & 0.28 \\
\hline & & rer does not Granger Cause roy & 0.01 \\
\hline \multirow[t]{2}{*}{ roy \& mos } & 1 & roy does not Granger Cause mos & $4.09 *$ \\
\hline & & mos does not Granger Cause roy & 0.39 \\
\hline
\end{tabular}

Note: $* * *, * *, *$ denote rejection of null hypothesis at the $99 \%, 95 \%$ and $90 \%$ level of significance, respectively. 

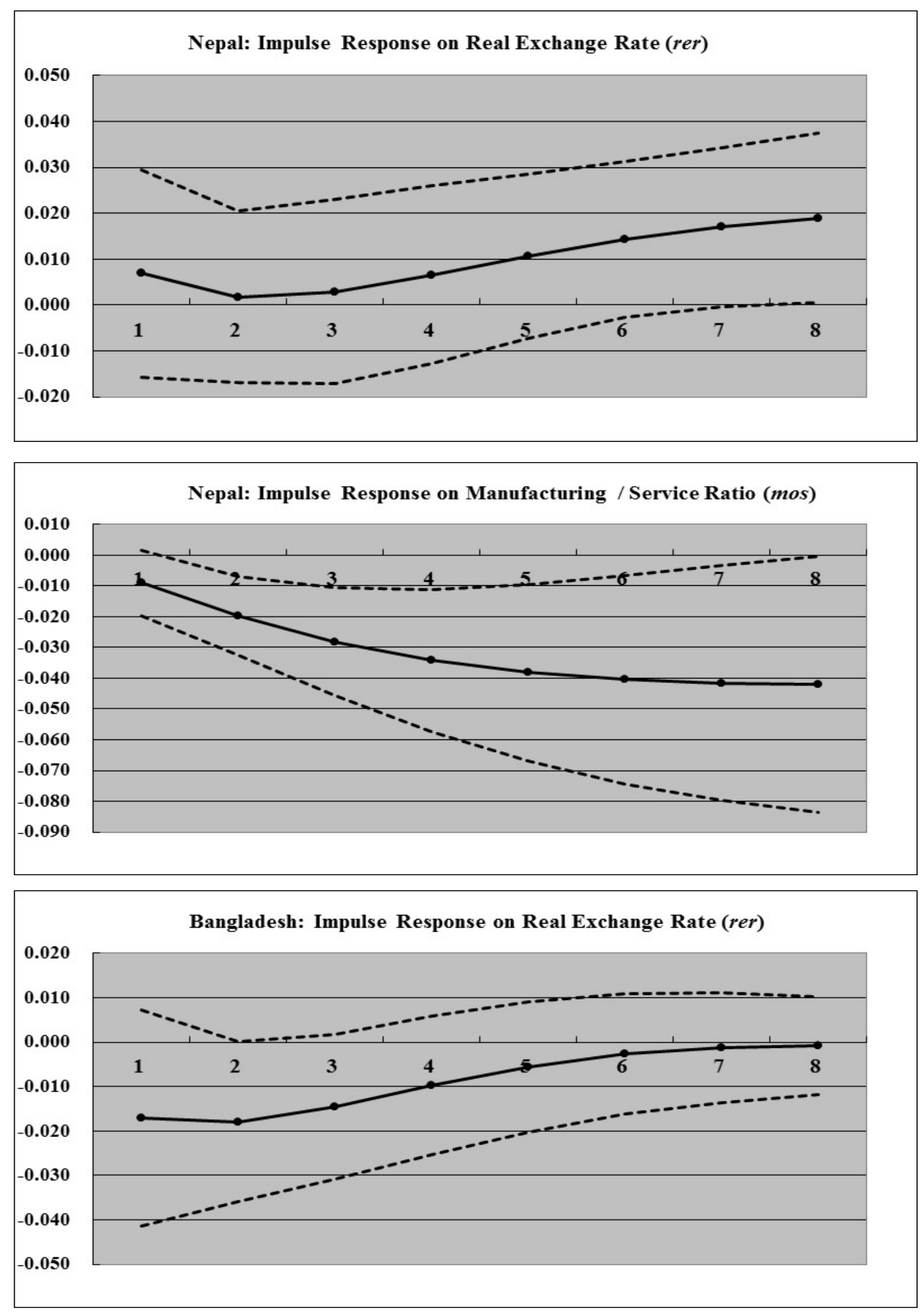


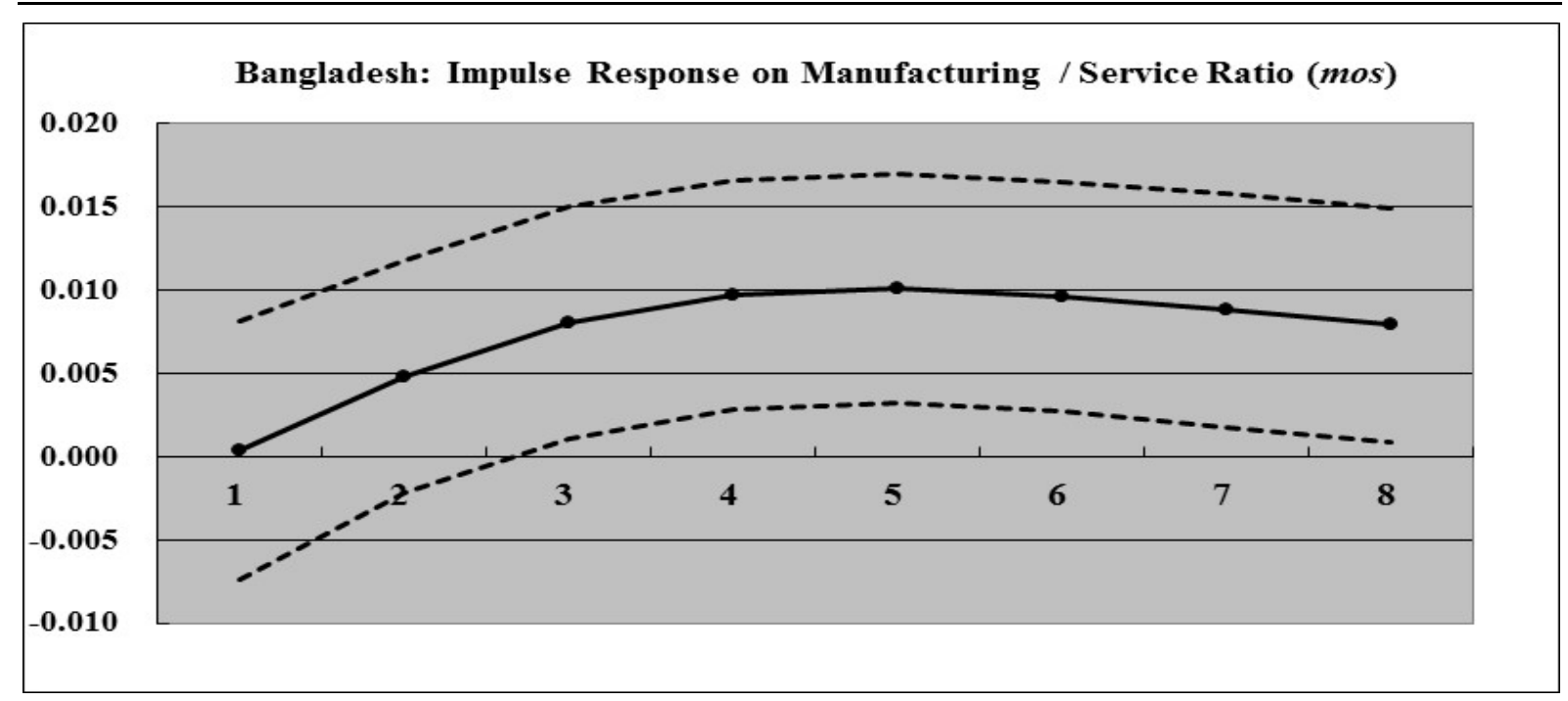

Note: The dotted lines denote a 95 percent error band over 8-year horizons.

Figure 4: Impulse Responses to Remittance Shock

The next question then arises what makes a contrast in the Dutch Disease effects of received remittances between Nepal and Bangladesh. The first perspective is the difference in their demand structure. Table 5 reports that on the average for 2000-2013, the share of "gross fixed capital formation” to GDP as well as that of "exports of goods and services” has been larger in Bangladesh than in Nepal, whereas that of "household consumption expenditures" has been greater in Nepal than in Bangladesh. This means that in Bangladesh the received remittances would tend to be allocated more to investment, thereby contributing to capital accumulation, while in Nepal the remittances would be used more for consumption. In this sense, the long-term effects of remittances suggested by Bourdet and Falck (2007) would be more applicable to Bangladesh.

The second perspective is the contrast in governmental industrial policies between both countries. Bangladesh has taken a positive stance to raise manufacturing sectors since the 1990s. The positive stance was typically shown in the industrial policy package in 2010 (see Bhuyan, 2010). The proposed industrial policy envisaged a clear target on manufacturing: an increase in the industry sector's share in GDP to 40 percent by 2021 from the present 28 percent, and sought to raise the proportion of the workforce employed in industry to 25 percent of the country's total labour force by 2021 from 16 percent now. For materializing the target, the policy gave priority to providing the industrial sector with adequate facilities of electricity, gas and water, and other physical infrastructure like road, rail transport and telecommunications. It also put an emphasis on establishing economic zones, industrial parks, and export processing zones to attract foreign direct investments in manufacturing sectors. On the other hand, Nepal has had no specific industrial policies as far as manufacturing sectors are concerned. This difference in the policy efforts between Bangladesh and Nepal would create a contrast in the Dutch Disease effects of received remittances between both countries: the manufacturing-promoting policies in Bangladesh would prevent the Dutch Disease from evolving, while no specific policies in Nepal would allow it to occur. 
Table 5: Demand Structure in Nepal and Bangladesh

\begin{tabular}{lll}
\hline \% of GDP during 2000-2013 & Nepal & Bangladesh \\
\hline Household consumption expenditure & 80.2 & 74.6 \\
Gross fixed capital formation & 20.6 & 26.2 \\
Exports of goods and services & 14.4 & 15.9 \\
\hline
\end{tabular}

Source: UNCTAD Stat, http://unctadstat.unctad.org/EN/.

\section{Concluding Remarks}

This paper examined the Dutch Disease effects of international migrant remittances by using a VAR estimation focusing on Nepal and Bangladesh. The reason for targeting two economies was that the differences in their economic performances could shed light on what kinds of mechanisms make the received remittances lead to or not to the Dutch Disease. The study identified the existence of the Dutch Disease in Nepal, but not in Bangladesh, judging from the causalities and dynamic responses from remittances to manufacturing-services ratio.

We speculate that the contrast in the Dutch Disease effects might come from the differences in the demand structure and policy efforts for manufacturing development between both economies: in Bangladesh the received remittances would tend to be allocated more to investment, thereby contributing to capital accumulation, while in Nepal the remittances would be used more for consumption; and Bangladesh has taken a positive stance to raise manufacturing sectors through the development of infrastructure and special economic zones since the 1990s, whereas Nepal has had no specific industrial policies as far as manufacturing sectors are concerned. The strategic implication of the empirical outcomes is the significance in enhancing the institutional quality to promote appropriate industrial policies to avoid the Dutch Disease under remittance-dependent economies.

\section{References}

Acosta, P. A., Calderon, C., Fajnzylber, P., \& Lopez, H. (2008). What is the Impact of International Migrant Remittances on Poverty and Inequality in Latin America? World Development, 36, 89-114. http://dx.doi.org/10.1016/j.worlddev.2007.02.016

Acosta, P. A., Lartey, E. K. K., \& Mandelman, F. S. (2009). Remittances and the Dutch Disease. Journal of International Economics, 79, 102-116. http://dx.doi.org/10.1016/j.jinteco.2009.06.007

Adams, R., \& Page, J. (2005). Do International Migration and Remittances Reduce Poverty in Developing Countries? World Development, 33, 1645-69. http://dx.doi.org/10.1016/j.worlddev.2005.05.004

Aggarwal, R., Demirguc-Kunt, A., \& Peria, M. (2006). Do Workers’ Remittances Promote Financial Development? World Bank Policy Research Working Paper No. 3957, World Bank. http://dx.doi.org/10.1596/1813-9450-3957 
Bhuyan, A. R. (2010). Bangladesh Industrial Policy 2010: A Critical Appraisal. Thoughts on Economics, 20, 1-16.

Bourdet, Y., \& Falck, H. (2006). Emigrants’ Remittances and Dutch Disease in Cape Verde. International Economic Journal, 20, 267-284. http://dx.doi.org/10.1080/10168730600879323

Chowdhury, M. (2011). Remittances Flow and Financial Development in Bangladesh. Economic Modelling, 28(6), 2600-2608. http://dx.doi.org/10.1016/j.econmod.2011.07.013

Corden, W. M., \& Neary, J. P. (1982). Booming sector and de-industrialization in a small open economy. Economic Journal, 92, 825-848. http://dx.doi.org/10.2307/2232670

Fayad, G. (2011). Remittances: Dutch disease or export-led growth? OxCarre (Oxford Centre for the Analysis of Resource Rich Economies) Research Paper 57.

Gorlich, D., Omar, M., \& Christoph, T. (2007). Explaining Labour Market Inactivity in Migrant-Sending Families: Housework, Hammock, or Higher Education? Kiel Working Paper 1391, Kiel Institute for the World Economy, Kiel, Germany.

Johansen, S. (1995). Likelihood-based Inference in Cointegrated Vector Autoregressive Models. Oxford: Oxford $\quad$ University http://dx.doi.org/10.1093/0198774508.001.0001

Lartey, E. K. K., Mandelman, F. S., \& Acosta, P. A. (2012). Remittances, Exchange Rate Regimes and the Ditch Disease: A Panel Data Analysis. Review of International Economics, 20, 377-395. http://dx.doi.org/10.1111/j.1467-9396.2012.01028.x

Pesaran H. H., \& Shin Y. (1998). Generalized impulse response analysis in linear multivariate $\begin{array}{llll}\text { models. } & \text { Economics } & \text { letters, }\end{array}$ http://dx.doi.org/10.1016/s0165-1765(97)00214-0

Said, S., \& Dickey, D. A. (1984). Testing for unit roots in autoregressive-moving average models of unknown order. Biometrika, 71, 599-607. http://dx.doi.org/10.2307/2336570

Woodruff, C., \& Zenteno, R. (2001). Remittances and Microenterprises in Mexico. Graduate School of International Relations and Pacific Studies Working Paper No. 43, University of California, San Diego. http://dx.doi.org/10.2139/ssrn.282019

Yang, D. (2005). International Migration, Human Capital, and Entrepreneurship: Evidence from Philippine Migrants’ Exchange Rate Shocks. World Bank Policy Research Working Paper No. 3578, World Bank. http://dx.doi.org/10.1596/1813-9450-3578 
Notes

Note 1. The data of remittances and GDP are retrieved from UNCTAD Stat, http://unctadstat.unctad.org/EN/, and the foreign aid (ODA)-GNI ratio from OECD DAC data, http://www.oecd.org/dac/stats/data.htm.

Note 2. International migrant remittances to developing countries have become the second largest type of capital inflows after foreign direct investment, according to UNCTAD STAT. In comparison with foreign aids, the remittances has exceeded them in terms of GDP ratio, as was shown in the introduction.

Note 3. See the website: http://data.worldbank.org/indicator.

Note 4. See the website: http://unctadstat.unctad.org/EN/

\section{Copyright Disclaimer}

Copyright for this article is retained by the authors, with first publication rights granted to the journal.

This is an open-access article distributed under the terms and conditions of the Creative Commons Attribution license (http://creativecommons.org/licenses/by/3.0/). 